(RESEARCH ARTICLE)

\title{
Trade-offs in the process of enrichment of tree plantations in sanitary protection zones of enterprises regarding the peculiarities of potential accumulation of toxicants in the leaves of trees
}

\author{
Sklyarenko Anastasia Victorovna * \\ Department of Garden and Park Architecture, Dnipro State Agrarian and Economic University, S. Efremov 25, Dnipro, \\ 49600, Ukraine.
}

Publication history: Received on 24 March 2020; revised on 02 April 2020; accepted on 04 April 2020

Article DOI: https://doi.org/10.30574/wjarr.2020.6.1.0079

\begin{abstract}
Plants serve as a versatile filter that is capable of purifying the atmospheric air from various toxic substances. In this study we investigate the green areas of sanitary protection zones of PrJSC "Ukrgrafit" and Zaporizhzhya Aluminium Plant PJSC industrial enterprises in the city of Zaporizhzhya, Ukraine. The forest stands growing in these zones were surveyed using the route method and the level of accumulation of water-soluble phenolic compounds, sulfur and fluorine in the leaves of plants was determined. On the basis of the data obtained during our investigation, compromise plans were proposed for enriching the tree flora growing in the area of green spaces of sanitary protection zones of PrJSC "Ukrgrafit" and Zaporizhzhya Aluminium Plant PJSC industrial enterprises, taking into account both their current and potential gas absorption capacity. Taking into account the environmental conditions and the natural resistance of plants, as far as protective plantations of the PrJSC "Ukrgrafit" enterprise and the species composition of forest belts of the Zaporizhzhya Aluminium Plant PJSC, the second and the fifth variants in the first case, as well as the fifth and the sixth variants in the second case, were determined as being the best options available for the purpose of tree flora enrichment.
\end{abstract}

Keywords: Accumulation; Flourine; Industrial enterprises; Phenolic compounds; Plantation options; Species composition of trees; Sulfur dioxide; Tree flora

\section{Introduction}

Air pollution, which is a major problem in the civilized world, has a serious toxicological impact on the environment and is a threat to public health, causing cardiovascular [1-4], respiratory [5, 6] and various other diseases. Industrial processes are regarded as the main contributor to air pollution. Harmful pollutants that originate from the aforementioned sources include sulfur oxides [7-9] carbon oxides, fluorine, phenolic compounds, nitrogen oxides etc. $[10,11]$.

Contaminants can cause leaf tissue destruction (necrosis) [12-14]. Under the influence of chlorine gas, the following acute morphological and physiological effects on species of coniferous plants were described and assessed: chlorosis, necrosis, decreased photosynthetic efficiency, damage to chloroplast membranes [14-16]. Trees growing near industrial enterprises suffer from a decrease in the average leaf area with a higher percentage of said area being damaged [17]. Changes in the content of assimilation pigments under the influence of industrial pollution are observed $[18,19]$ and the rate of photosynthesis decreases [20]. Emissions of dangerous pollutants, which include fluorine, phenolic compounds and sulfur, can lead to contamination of agricultural land in Zaporizhzhya region, where grains and oilseeds are being grown. This will weaken Ukraine's food security and prevent international export commitments as a result of agricultural products rapidly deteriorating in quality [21].

\footnotetext{
* Corresponding author: Sklyarenko Anastasia Victorovna
} 
Green plantations of the sanitary protection zones of industrial enterprises act as a natural filter that retains solid particles [22-26], reduces the amount of dust [27, 28]. Plants are capable of accumulating harmful toxicants [13,17, 29-30], whereby their concentration in the leaves increases during the growing season [31]. This limits the spread of ingredients of industrial emissions not only to the city's living areas but also to the surrounding crop fields.

The aim of the study is to offer compromise plans for the enrichment of green spaces of sanitary protection zones of PrJSC "Ukrgrafit" and Zaporizhzhya Aluminium Plant PJSC industrial enterprises, taking into account their potential gas absorption capacity.

\section{Material and methods}

Research was carried out in the areas of sanitary protection zones of a number of enterprises in the city of Zaporizhzhya

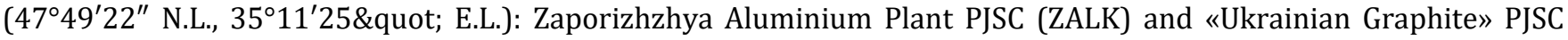
(Ukrgrafit). Inspection of the forest stands of the sanitary protection zones of the investigated enterprises was carried out by the route method, taking into account all of the trees growing in each specific forest belt. The study of the species composition of the tree flora was performed according to [32] using reference publications [33]. Plant names were given by [34].

Water-soluble phenolic compounds were detected from an aqueous extract of phytomass by the method of [35], using a Folin-Ciocalte reagent. Fluoride content was determined by L.A. Khazemova et al. [36]. Determination of sulfur content was performed spectrophotometrically by the method of A.D. Mochalova (1975) [37].

The total mass of leaves obtained from studying the model tree was determined by the formula given by V.G. Nesterov and B.M. Bobilev (1967) [38]:

$P=\frac{\pi}{4} \rho\left(l \sum D_{j}^{2}+\frac{1}{3} l_{1} D_{j+1}^{2}\right)$

where $P$ - total mass of tree leaves, kg; $\rho$ - the weight of leaves per $1 \mathrm{~m}^{3}$ of the crown, $\mathrm{kg} / \mathrm{m}^{3} ; D_{j}-$ diameters of the crown, $\mathrm{m} ; \mathrm{l}$ - the distance between the cross-sections, $\mathrm{m} ; l_{1}-$ length of the apex, $\mathrm{m}$.

The average content of a particular toxicant in the leaves of tree plants was then calculated.

H.M. Il'kun (1978) [39] is credited with the idea of using woody plants to purify the atmospheric air from pollutants, namely the idea of a balanced method, which assumes not only the content of pollutants in the leaves but their potential outflow to other organs or its removal by precipitation (a certain percentage depending on a given month of a growing season). This approach makes it possible to assess the potential filtering role of plants and not just the end result of the accumulation of pollutants in the leaves of tree species.

Environmental purification role in the absorption of sulfur by tree plantations was assessed using the formula by S. A. Sergeychik (1997) [40]:

$$
\mathrm{P}=\mathrm{K} * \mathrm{Y} \frac{\mathrm{TB}}{\mathrm{Ty}}
$$

$\mathrm{P}$ - absorption capacity of 1 ha of plantations per growing season, kg/ha; $\mathrm{Y}$ - dry phytomass of leaves and/or needles, $\mathrm{kg}$; $\mathrm{K}$ - coefficient of physiologically acceptable accumulation of sulfur (hardwood - 0,002, coniferous - 0,0001); Tв the duration of the growing season; Ty - period of time needed for the removal of sulfur from leaves and/or needles (10 days).

Creating a multicriteria optimization model was carried out in the following sequence. Biodiversity is provided by $\mathrm{N}$ species of trees. In the conditions of sanitary protection zones of such enterprises as PrJSC "Ukrgrafit" and Zaporizhzhya Aluminium Plant PJSC 20 species of trees are being grown.

But in specific contexts, it is advisable to choose the most efficient and naturally resistant species, depending on the level of contamination with certain toxicants, which makes specific the value of $\mathrm{N}$. 
Let $x$ be the number of new trees of the $i$-th species to be planted $i=1 \ldots N$. Adhering to the content, all entered unknowns accept only non-negative integer values, that is, $\mathrm{x}_{\mathrm{i}} \geq 0$.

The composition of the tree flora of protective forest strips is described by known quantities (except for trees that are to be replaced):

$\mathrm{yi}^{1}$ - number of young trees of the i-th species,

$\mathrm{yi}^{2}-$ middle age trees of the i-th species,

$\mathrm{yi}^{3}-$ mature trees of the $\mathrm{i}$-th species, $\mathrm{i}=1 \ldots \mathrm{N}$.

Then let $A_{1}$ and $A_{2}$ determine the needs of supplementing the quantitative composition of the trees growing in the green zones, taking into account the condition of the existing plantations and the area of the territory of the sanitary protection zone without plantations. From this we obtain our restrictions here:

$\sum_{i=1}^{N} x_{i} \geq A_{1},(1)$

$\sum_{i=1}^{N} x_{i} \leq A_{2}$

Species diversity requirements (no less than B tree species) are taken into account by the ratio:

$\sum_{i=1}^{N} \operatorname{sign}\left(x_{i}\right) \geq B .(3)$

Let's denote by $a_{i}$ the basic fluorine accumulation $(\mathrm{g}), \mathrm{b}_{\mathrm{i}}$ - basic accumulation of phenolic compounds and $\mathrm{c}_{\mathrm{i}}$ - baseline sulfur accumulation depending on the level of pollutant concentration around a given enterprise per phytomass $(\mathrm{kg})$, produced by one tree of the $\mathrm{i}$-th species, $\mathrm{i}=1 \ldots \mathrm{N}$.

The production of plant leaf phytomass in the sanitary protection zones of PrJSC "Ukrgrafit" and Zaporizhzhya Aluminium Plant PJSC industrial enterprises is averaged for all species in each age category and amounts to:

for young trees $k_{1}=3 \mathrm{~kg}$,

for middle-aged trees $k_{2}=10 \mathrm{~kg}$,

for mature trees $k_{3}=6 \mathrm{~kg}$,

The total amount of uptake of pollutants in the protective forest strips of these enterprises was calculated by the formulas given below:

for fluorine: $F_{1}=\sum_{\mathrm{i}=1}^{N}\left(\mathrm{x}_{\mathrm{i}} \cdot k_{1}+\sum_{j=1}^{3} y_{i}^{j} \cdot k_{j}\right) \cdot a_{i},(4)$

for phenolic compounds: $F_{2}=\sum_{\mathrm{i}=1}^{N}\left(\mathrm{x}_{\mathrm{i}} \cdot k_{1}+\sum_{j=1}^{3} y_{i}^{j} \cdot k_{j}\right) \cdot \mathrm{b}_{\mathrm{i}}$

for sulfur: $F_{3}=\sum_{\mathrm{i}=1}^{N}\left(\mathrm{x}_{\mathrm{i}} \cdot k_{1}+\sum_{j=1}^{3} y_{i}^{j} \cdot k_{j}\right) \cdot \mathrm{c}_{\mathrm{i}}$

Alternating selection in the models from (1)-(6) as the maximized criterion of the functions from (4)-(6) will allow to find the optimal arrangement for the enrichment of green zones by the tree species with a maximum absorption capacity for fluorine, phenolic compounds and sulfur on the yet unused territory and to realize the replacement of the deadwood.

Let's mark in our plans $F_{j}^{\min }$ and $F_{j}^{\max }$ - the largest and smallest total accumulation of pollutants.

In order to determine the compromise plans for the enrichment of sanitary protection zones of PrJSC "Ukrgrafit" and Zaporizhzhya Aluminium Plant PJSC industrial enterprises, it is possible to determine the absorption values in the range $\left[F_{j}^{\min }, F_{j}^{\max }\right]$ according to the level of accumulation of each of the toxicants and also to obtain alternative models of the quantitative composition of tree species growing near the industrial enterprises. 
The quantitative assessment of woody plants did not take into account the number of the self-seeding species growing in the area of sanitary protection zones of the PrJSC "Ukrgrafit" and Zaporizhzhya Aluminium Plant PJSC industrial enterprises.

\section{Results and discussion}

The practical implementation of the proposed multicriteria optimization model according to formulas (1)-(6) was realized using the MS Excel spreadsheet environment for two enterprises in the city of Zaporizhzhya - PrJSC "Ukrgrafit" and Zaporizhzhya Aluminium Plant PJSC.

We have examined the green plantations of sanitary protection zones of PrJSC "Ukrgrafit" and Zaporizhzhya Aluminium Plant PJSC industrial enterprises for which the species composition of the tree flora amounts to $\mathrm{N}=20$ species [41, 42]. The quantitative characteristics of the uptake of pollutants such as sulfur, phenolic compunds, fluorine and the quantitative composition of the forest stands of the protective forest strips of enterprises (except for the trees that are described as dead-wood and are to be replaced) are contained in Tables 1 and 3.

Table 1 Input parameters of the protective plantation of the "Ukrgrafit" enterprise

\begin{tabular}{|c|c|c|c|c|c|c|c|c|c|c|}
\hline № & Tree species & $\begin{array}{l}\text { Number } \\
\text { trees }\end{array}$ & of & $a_{i}, g / k g$ & $b_{i} g / k g$ & $c_{i}, g / k g$ & $\mathbf{y}_{\mathrm{i}}{ }^{1}$ & $\mathbf{y i}^{2}$ & $\mathbf{y i}^{3}$ & Moribund \\
\hline 1 & Acer negundo & 2 & & 0,06762 & 0,4344 & 3,8 & 2 & 0 & & \\
\hline 2 & Acer platanoides & 13 & & 0,08137 & 0,2412 & 4 & 7 & 5 & & 1 \\
\hline 3 & Ailanthus altissima & 53 & & 0,09928 & 0,4395 & 3 & 5 & 48 & & \\
\hline 4 & Catalpa bignonioides & 1 & & 0,08549 & 0,3962 & 4,1 & & 1 & & \\
\hline 5 & Elaeagnus angustifolia & 1 & & 0,14971 & 0,4938 & 2,8 & & 1 & & \\
\hline 6 & Fraxinus lanceolata & 37 & & 0,09928 & 0,2706 & 4 & 21 & 16 & & \\
\hline 7 & Juglans regia & 9 & & 0,08562 & 0,4395 & 4,1 & 6 & 3 & & \\
\hline 8 & Malus domestica & 4 & & 0,09928 & 0,4395 & 4,1 & & 4 & & \\
\hline 9 & Morus alba & 116 & & 0,09774 & 0,2388 & 2,7 & & 115 & & 1 \\
\hline 10 & Populus alba & 70 & & 0,12475 & 0,7422 & 6,1 & & 60 & 10 & \\
\hline 11 & Populus nigra & 3 & & 0,12781 & 1,0333 & 4,9 & & & 3 & \\
\hline 12 & Populus pyramidalis & 1 & & 0,11596 & 0,5664 & 4,1 & & & 1 & \\
\hline 13 & Populus simonii & 4 & & 0,13232 & 0,8172 & 4,5 & & 4 & & \\
\hline 14 & Pyrus communis & 1 & & 0,09928 & 0,4395 & 4,1 & & 1 & & \\
\hline 15 & Robinia pseudoacacia & 365 & & 0,06136 & 0,3030 & 5,1 & 14 & 285 & 61 & 5 \\
\hline 16 & Salix alba & 2 & & 0,11074 & 0,2922 & 4,2 & & 2 & & \\
\hline 17 & Thuja orientalis & 4 & & 0,09928 & 0,4395 & 4,1 & 3 & 1 & & \\
\hline 18 & Tilia cordata & 7 & & 0,0628 & 0,2172 & 5 & 4 & 3 & & \\
\hline 19 & Ulmus laevis & 61 & & 0,10534 & 0,2418 & 4,1 & 2 & 35 & 24 & \\
\hline 20 & Ulmus carpinifolia & 183 & & 0,09956 & 0,3054 & 2,9 & 3 & 134 & 42 & 4 \\
\hline
\end{tabular}

The green area of the protective forest strip of the PrJSC "Ukrgrafit" enterprise consists of 937 trees. The assessment of the need to supplement the quantitative composition of trees, to replace the dead-wood in the sanitary protection zone of this enterprise and to ensure the biodiversity is characterized by the following values: $A_{1}=73, A_{2}=88,=7$. 
The compromise plans of supplementing the trees in order to fill the gaps in rows and empty regions of land and replacing the dead-wood are outlined in (Table 2 ).

The selection of plants for the purpose of enrichment (supplementation) should also take into account the environmental conditions of growth and resistance of plants to pollutants produced by these enterprises. In the first, fourth and last (sixth) embodiment, the trees of the Salicacea family appear to be quantitatively dominant. In the third variant, the largest number of trees proposed for planting in the sanitary protection zone of the "Ukrgrafit" enterprise belongs to the Acer negundo specimens. This species is characterized by high self-healing ability, which affects negatively the structure of the plantation. Natural seed renewal of Acer negundo is commonly observed on the fringes of the objects of landscaping, parkways, degraded communities, and the like. Species that spontaneously propagate in natural and artificial ecosystems pose a threat to their stability and natural resistance [43]. In the second and fifth variants, Ailanthus altissima, Morus alba, Robinia pseudoacacia and representatives of the Ulmaceae family predominate. The species proposed in these variants are characterized by their considerable resistance to the ecological conditions of the Ukrainian Steppe but also to the significant concentrations of toxicants.

Table 2 Compromise variants of enriching the plantations of sanitary protection zones of the "Ukrgrafit" enterprise are assessed using the models (1)-(6)

\begin{tabular}{|c|c|c|c|c|c|c|c|}
\hline \multirow[t]{2}{*}{ Values } & \multirow[t]{2}{*}{ Tree species } & \multicolumn{6}{|c|}{ Alternative variant } \\
\hline & & 1 & 2 & 3 & 4 & 5 & 6 \\
\hline$x_{1}$ & Acer negundo & & & 38 & & & 1 \\
\hline$x_{2}$ & Acer platanoides & & & & & & \\
\hline$x_{3}$ & Ailanthus altissima & & 28 & & 16 & 17 & 1 \\
\hline$x_{4}$ & Catalpa bignonioides & & & & & & \\
\hline$x_{5}$ & Elaeagnus angustifolia & 27 & & & & & 3 \\
\hline$x_{6}$ & Fraxinus lanceolata & & & & & 5 & \\
\hline$x_{7}$ & Juglans regia & & & & & 5 & 1 \\
\hline$x_{8}$ & Malus domestica & & & & & & 1 \\
\hline$x_{9}$ & Morus alba & & 20 & & 12 & 12 & \\
\hline$x_{10}$ & Populus alba & 14 & 4 & 16 & 13 & & 13 \\
\hline$x_{11}$ & Populus nigra & 15 & & 18 & 17 & & 24 \\
\hline$x_{12}$ & Populus pyramidalis & 9 & & 10 & 9 & & 6 \\
\hline$x_{13}$ & Populus simonii & 18 & & & & & 38 \\
\hline$x_{14}$ & Pyrus communis & & & & & & 1 \\
\hline$x_{15}$ & Robinia pseudoacacia & 0 & 27 & & 1 & 23 & \\
\hline$x_{16}$ & Salix alba & 1 & & 1 & 1 & & \\
\hline$x_{17}$ & Thuja orientalis & & & & & & \\
\hline$x_{18}$ & Tilia cordata & & 2 & & 12 & & \\
\hline$x_{19}$ & Ulmus laevis & 3 & 5 & 3 & 3 & 12 & \\
\hline$x_{20}$ & Ulmus carpinifolia & & 2 & & & 12 & \\
\hline & $F_{1}$ & 745,9 & 734,1 & 736,4 & 737,7 & 734,3 & 744,5 \\
\hline & $F_{2}$ & 2902,3 & 2811,7 & 2882,1 & 2859,7 & 2803,1 & 2935,2 \\
\hline & $F_{3}$ & 35388,0 & 35277,8 & 35441,3 & 35363,4 & 35258,5 & 35515,5 \\
\hline
\end{tabular}

Remark: $F_{1}, F_{2}, F_{3}$ - the content of toxicants (fluorine, phenolic compounds and sulfur, g) in the leaves of tree species that are growing in the green area of the enterprise, taking into account the factor of enrichment of green plantations.

Tree plantations of the sanitary protection zone of the "Ukrgrafit" enterprise, which amount to 937 specimens, produce $8230 \mathrm{~kg}$ of phytomass. Each year, $0.7 \mathrm{~kg}$ of fluorine, $2.7 \mathrm{~kg}$ of phenolic compounds and $34.3 \mathrm{~kg}$ of sulfur are concentrated in the leaves of tree plants. However, the actual forest absorption potential is much higher. In general, the protective plantations of the enterprise absorb $296.3 \mathrm{~kg}$ of sulfur or $592.6 \mathrm{~kg}$ of sulfur dioxide, $7.9 \mathrm{~kg}$ of phenolic compounds and 
$1.9 \mathrm{~kg}$ of fluorine. In case of enrichment and replacement of deadwood with new breeds, the sanitary protection zone of the "Ukrgrafit" enterprise will absorb $0.3 \mathrm{~kg}$ more phenolic compounds from the atmospheric air as well as $10 \mathrm{~kg}$ more sulfur. In 10 years' time, the forest belt of the "Ukrgrafit" enterprise will absorb $328.0 \mathrm{~kg}$ of sulfur $\left(656.0 \mathrm{~kg} \mathrm{of} \mathrm{SO}_{2}\right), 8.8$ $\mathrm{kg}$ of phenolic compunds and $2.0 \mathrm{~kg}$ of fluorine (Fig. 1).

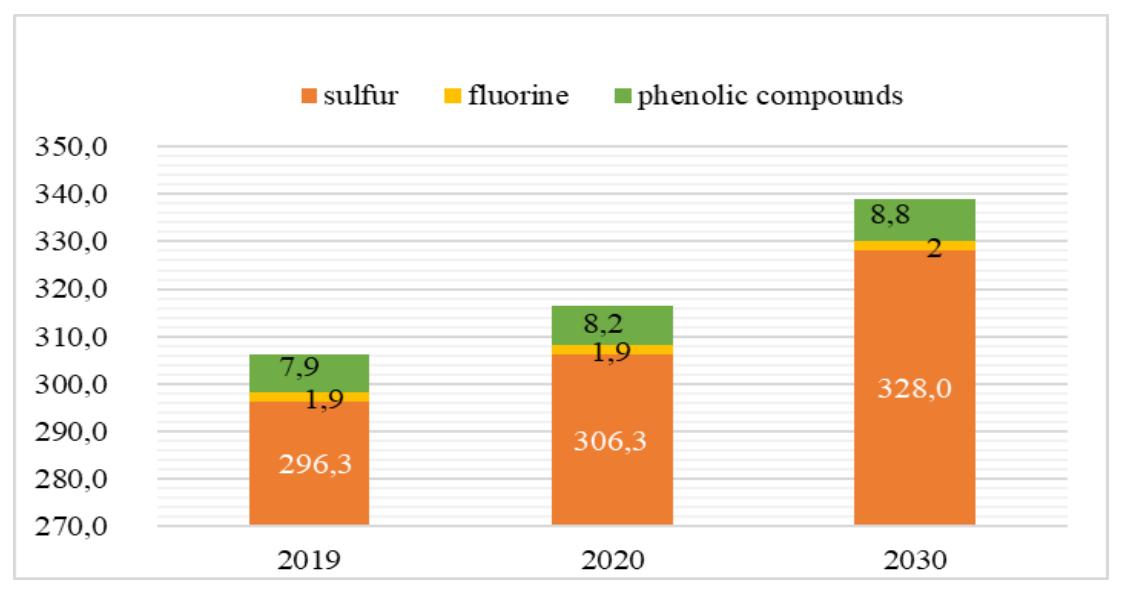

Figure 1 Actual (2019) and projected (2020,2030) absorption capacity of plantations of the sanitary protection zone of "Ukrgarfit" enterprise, kg.

Plantation of the sanitary protection zone of the Zaporizhzhya Aluminium Plant PJSC industrial enterprise consists of 954 trees in total.

Table 3 Input parameters of the protective plantation of the Zaporizhzhya Aluminium Plant PJSC industrial enterprise

\begin{tabular}{|c|c|c|c|c|c|c|c|c|c|}
\hline № & Tree species & Quantity & $a_{i}, \mathbf{g} / \mathbf{k g}$ & $\mathbf{b}_{\mathrm{i}} \mathbf{g} / \mathbf{k g}$ & $c_{i}, \mathbf{g} / \mathbf{k g}$ & $y_{i^{1}}$ & $\mathbf{y i}^{2}$ & $\mathbf{y i}^{3}$ & Moribund \\
\hline 1 & Acer pseudoplatanus & 2 & 0,44308 & 0,3456 & 3,5 & 1 & 1 & & \\
\hline 2 & Aesculus hippocastanum & 11 & 0,60026 & 0,1284 & 3,6 & & 11 & & \\
\hline 3 & Ailanthus altissima & 27 & 0,43326 & 0,6192 & 2,7 & 2 & 25 & & \\
\hline 4 & Betula pendula & 2 & 0,28071 & 0,3718 & 5 & & 2 & & \\
\hline 5 & Catalpa bignonioides & 16 & 0,49721 & 0,3012 & 3,9 & 6 & 10 & & \\
\hline 6 & Fraxinus lanceolata & 57 & 0,42083 & 0,2184 & 3,4 & 9 & 42 & & 6 \\
\hline 7 & Morus alba & 9 & 0,5226 & 0,1692 & 1,9 & 3 & 6 & & \\
\hline 8 & Picea pungens & 13 & 0,44308 & 0,3718 & 3,5 & 4 & 9 & & \\
\hline 9 & Platanus acerifolia & 1 & 0,2891 & 0,3718 & 3,5 & & 1 & & \\
\hline 10 & Populus alba & 29 & 0,64267 & 0,6870 & 4,5 & & 24 & 5 & \\
\hline 11 & Populus nigra & 5 & 0,67011 & 0,9264 & 3,7 & & 4 & 1 & \\
\hline 12 & Populus Simonii & 1 & 0,57936 & 0,6798 & 3,7 & & 1 & & \\
\hline 13 & Quercus robur & 3 & 0,44308 & 0,3718 & 3,5 & 3 & 0 & & \\
\hline 14 & Robinia pseudoacacia & 348 & 0,2756 & 0,2610 & 4,2 & 14 & 325 & 5 & 4 \\
\hline 15 & Salix alba & 15 & 0,6029 & 0,2304 & 3,2 & & 9 & 6 & \\
\hline 16 & Sorbus aucuparia & 2 & 0,44308 & 0,3718 & 3,5 & & 2 & & \\
\hline 17 & Thuja orientalis & 6 & 0,44308 & 0,3718 & 3,5 & 1 & 5 & & \\
\hline 18 & Tilia cordata & 14 & 0,26031 & 0,1830 & 4 & 6 & 6 & & 2 \\
\hline 19 & Ulmus laevis & 32 & 0,27071 & 0,2568 & 3,5 & 2 & 25 & 4 & 1 \\
\hline 20 & Ulmus carpinifolia & 361 & 0,31054 & 0,1992 & 2,1 & 6 & 329 & 21 & 5 \\
\hline
\end{tabular}

Plans to supplement the quantitative composition of the green space of the Zaporizhzhya Aluminium Plant PJSC were outlined using the MS Excel spreadsheets environment. The assessment of the need for the renewal of the quantitative composition of the trees in the sanitary protection zone of the Zaporizhzhya Aluminium Plant PJSC, while ensuring the biodiversity is characterized by the following values: $A_{1}=64, A_{2}=82, B=7$. Compromise plans for the enrichment 
(supplementation) of protective forest belts of the Zaporizhzhya Aluminium Plant PJSC industrial enterprise are demonstrated in Table 4.

Table 4 Compromise variants of enriching the plantations of the sanitary protection zone of the Zaporizhzhya Aluminium Plant PJSC are assessed using models (1)-(6)

\begin{tabular}{|c|c|c|c|c|c|c|c|}
\hline \multirow[t]{2}{*}{ Values } & \multirow[t]{2}{*}{ Tree species } & \multicolumn{6}{|c|}{ Alternative variants } \\
\hline & & 1 & 2 & 3 & 4 & 5 & 6 \\
\hline$x_{1}$ & Acer pseudoplatanus & & & & & & \\
\hline$x_{2}$ & Aesculus hippocastanum & 12 & 10 & & & & \\
\hline$x_{3}$ & Ailanthus altissima & & & 5 & & 17 & 14 \\
\hline$x_{4}$ & Betula pendula & & & & & & \\
\hline$x_{5}$ & Catalpa bignonioides & & 1 & & & & \\
\hline$x_{6}$ & Fraxinus lanceolata & & & 45 & 26 & & 1 \\
\hline$x_{7}$ & Morus alba & 3 & 1 & & & 9 & \\
\hline$x_{8}$ & Picea pungens & & & & & & \\
\hline$x_{9}$ & Platanus acerifolia & & & & & & \\
\hline$x_{10}$ & Populus alba & 17 & 15 & 6 & & & 6 \\
\hline$x_{11}$ & Populus nigra & 20 & 18 & 1 & 1 & 4 & 1 \\
\hline$x_{12}$ & Populus Simonii & 10 & 8 & & & & \\
\hline$x_{13}$ & Quercus robur & & & & & & \\
\hline$x_{14}$ & Robinia pseudoacacia & & & 20 & 10 & 27 & 37 \\
\hline$x_{15}$ & Salix alba & 19 & 11 & & & & \\
\hline$x_{16}$ & Sorbus aucuparia & & & & & & \\
\hline$x_{17}$ & Thuja orientalis & & & & & & 3 \\
\hline$x_{18}$ & Tilia cordata & & & & & 1 & \\
\hline$x_{19}$ & Ulmus laevis & & & & 42 & & \\
\hline \multirow[t]{4}{*}{$x_{20}$} & Ulmus carpinifolia & & & & & 18 & \\
\hline & $F_{1}$ & 3065,8 & 3037,8 & 3011,1 & 2994,0 & 3010,3 & 3021,2 \\
\hline & $F_{2}$ & 2427,4 & 2410,9 & 2369,7 & 2359,4 & 2389,8 & 2377,4 \\
\hline & $F_{3}$ & 29171,4 & 28992,2 & 29112,3 & 29101,2 & 29022,1 & 29192,6 \\
\hline
\end{tabular}

The proposed plans for supplementing the plantations of the sanitary protection zone of the Zaporizhzhya Aluminium Plant PJSC are somewhat different, but the difference in the accumulated toxicants is not significant. When selecting species of woody plants, resistance to pollutants and the ability to grow in accordance with the given environmental conditions should be taken into account. In the first and second variants, considerable preference is given to Aesculus hippocastanum and Populus alba. In the third and fourth embodiment - Fraxinus lanceolata and Robinia pseudoacacia. In the last two, the maximum number of proposed trees is attributed to such species as Robinia pseudoacacia and Ailanthus altissima. V.P. Bessonova and O.A. Ponomaryova (2016), in their works pointed out that plantations of Robinia pseudoacacia in the southern regions of Ukraine appear to be the most dominant and perform protective, purifying functions and are characterized by a high level of vitality [44]. The same characteristics are applicable to Ailanthus altissima. Therefore, the most promising are the last two variants of supplementing the protective forest belts of the sanitary protection zone of the Zaporizhzhya Aluminium Plant PJSC. 
Provided the young trees are to be planted, the leaves of woody plants growing in the area of plantations of the sanitary protection zone of the Zaporizhzhya Aluminium Plant PJSC industrial enterprise will accumulate almost $3.0 \mathrm{~kg}$ of fluorine, $4.4 \mathrm{~kg}$ of phenolic compounds and approximately $29.1 \mathrm{~kg}$ of sulfur.

Taking into account the loss of phytotoxicants through leaves (as described in the calculation of their accumulation for the trees growing in the sanitary protection zone of the "Ukrgrafit" enterprise for the entire period of the growing season) and outflow to other organs (Il'kun, 1978), $316.3 \mathrm{~kg}$ of sulfur, i.e. $632.6 \mathrm{~kg}$ of sulfur dioxide, is absorbed, as well as $8.6 \mathrm{~kg}$ of fluorine and $7.3 \mathrm{~kg}$ of phenolic compounds. As new trees are being planted and deadwood is being replaced, the role of sanitary protection zone of the Zaporizhzhya Aluminium Plant PJSC will increase with time. In all of the plans proposed (1-6), the accumulation potential will increase by $9 \mathrm{~kg}$ in the case of sulfur and will equal $325.2 \mathrm{~kg}$ of sulfur or $650.4 \mathrm{~kg}$ of sulfur dioxide. The absorption of fluorine and phenolic compounds will increase by 300 grams each. And only in 10 years' time the enriched plantation of the sanitary protection zone will absorb $9.6 \mathrm{~kg}$ of fluorine, $8.0 \mathrm{~kg}$ of phenolic compounds and $345 \mathrm{~kg}$ of sulfur (or $690 \mathrm{~kg}$ of $\mathrm{SO}_{2}$ ) (Fig. 2).

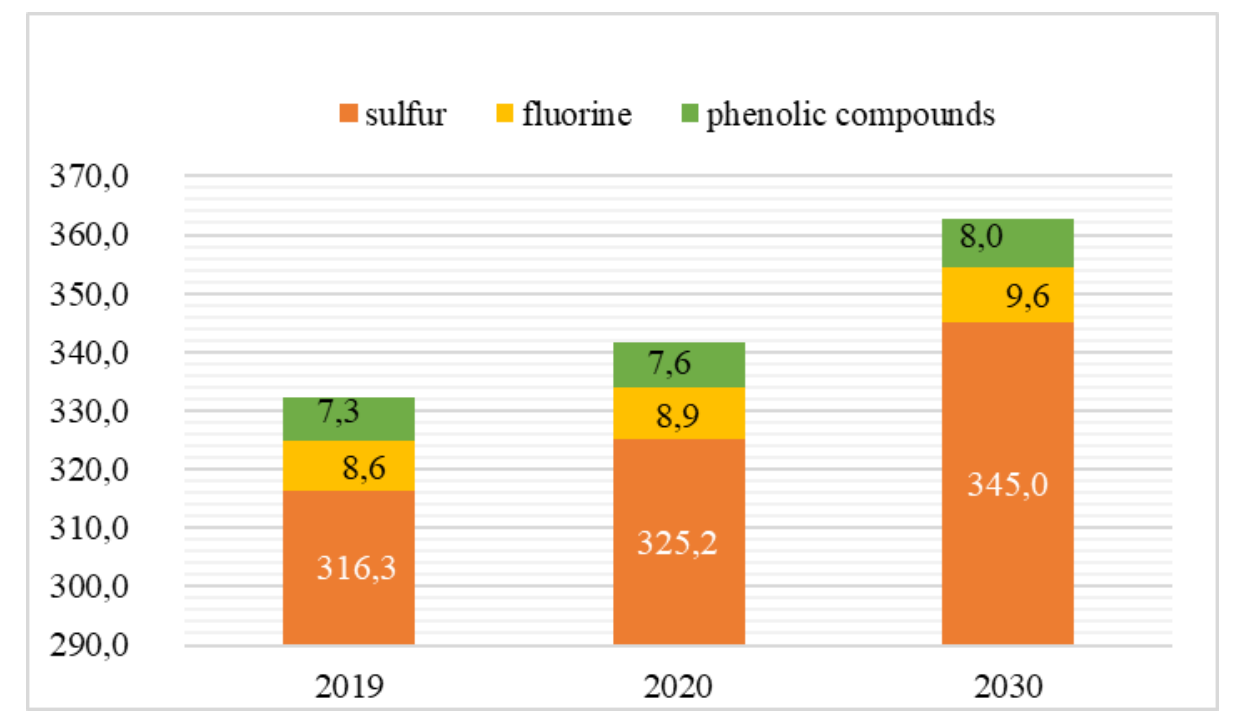

Figure 2 Actual (2019) and projected $(2020,2030)$ absorption capacity of plantations of the sanitary protection zone of the Zaporizhzhya Aluminium Plant PJSC, kg

In terms of 1 ha of permeable dense forest shelterbelt, the potential absorption capacity will be as follows: sulfur - 160 $\mathrm{kg}$ (or $320 \mathrm{~kg}$ sulfur dioxide), fluorine $-1.0 \mathrm{~kg}$, phenolic compounds $-4.3 \mathrm{~kg}$; and for the Zaporizhzhya Aluminium Plant PJSC it will be: sulfur - $166.5 \mathrm{~kg}$ (or $333 \mathrm{~kg}$ sulfur dioxide), fluorine $-4.6 \mathrm{~kg}$, phenolic compounds - $3.9 \mathrm{~kg}$. For comparison, the data from other authors on the purifying role of plantations of woody plants is listed below.

According to P.P. Yavornytskyi (2014) [45], 0.4 ha of sulfur gas and 0.1 tonnes of chlorides are absorbed by 1 ha of forest plantations. V.P. Tarabrin (1985) [46] indicates that one plant is able to absorb and neutralize $150 \mathrm{~g}$ of heavy metals, $900-1000 \mathrm{~g}$ of gaseous substances and 1 ha of green plantations of (500-700) trees inactivate $700-800 \mathrm{~kg}$ of gases during the growing season.

According to the estimates by W. H. Smith (1985) [47], 1 ha of forest absorbs $748 \mathrm{~kg}$ of SO2, or $374 \mathrm{~kg}$ of sulfur. In this case, the green phytomass of woody plants (856 kg) will contain $2.2 \mathrm{~g}$ of sulfur per $1 \mathrm{~g}$. 0.V. Chernyshenko (2010) [48], however, describes the figures given to us by W.H. Smith that are meant to estimate the capacity of plants to absorb gaseous substances as being overstated.

\section{Conclusion}

We have devised the compromising plans of replacing deadwood and enriching the protective plantations of PrJSC "Ukrgrafit" and Zaporizhzhya Aluminium Plant PJSC industrial enterprises. The aim is to improve the purifying role of woody plants growing in the green area of these enterprises. Considering environmental conditions and the natural resistance of plants, the second and the fifth in the case of protective forest belts of the "Ukrgrafit" enterprise as well as the fifth and sixth variants in the case of species composition of the Zaporizhzhya Aluminium Plant PJSC appear to be the best options for the purpose of enrichment (supplementation) of the aforementioned green plantations. 
Implementation of variants of compromise plans for the renewal of green areas will contribute to the growth of the role of protective forest strips in purifying the environment. Leaves of woody plants of the sanitary protection zone of the "Ukrgrafit" enterprise will absorb $160 \mathrm{~kg}$ of sulfur (or $320 \mathrm{~kg}$ of sulfur dioxide), 1,0 kg of fluorine and 4,3 kg of phenolic compounds. Whereas in the case of Zaporizhzhya Aluminium Plant PJSC, $166.5 \mathrm{~kg}$ of sulfur (or $333 \mathrm{~kg}$ of sulfur dioxide), $4.6 \mathrm{~kg}$ of fluorine and $3.9 \mathrm{~kg}$ of phenolic compounds will be absorbed.

\section{Compliance with ethical standards}

\section{Acknowledgments}

The author is thankful to Doctor of Economic Sciences, Professor Vasylieva N. K. for their assistance in creating a multicriteria optimization model.

\section{Disclosure of conflict of interest}

The author declares no conflicts of interest.

\section{Statement of ethical approval}

'The present research work does not contain any studies performed on animals/humans'.

\section{References}

[1] Brook RD, Franklin B, Cascio W, Hong Y, Howard G, Lipsett M, Luepker R, Mittleman M, Samet J, Smith SC and Tager I. (2004). Air Pollution and Cardiovascular Disease. Circulation, 21(109), 2655-2671.

[2] Bourdrel T, Bind MA, Béjot Y, Morel O and Argacha JF. (2017). Cardiovascular effects of air pollution. Arch Cardiovasc Dis, 110(11), 634-642.

[3] Routledge HC and Ayres JG. (2005). Air pollution and the heart. Occupational Medicine, 55, 439-447.

[4] Lee BJ, Kim B and Lee K. (2014). Air Pollution Exposure and Cardiovascular Disease. Toxicol Res, 30(2), 71-75.

[5] Genc S, Zadeoglulari Z, Fuss SH and Genc K. (2012). The Adverse Effects of Air Pollution on the Nervous System Journal of Toxicology, 1-23.

[6] Ghorani-Azam A, Riahi-Zanjani B and Balali-Mood M. (2016). Effects of air pollution on human health and practical measures for prevention in Iran. Journal of Research in Medical Sciences, 21(65), 1-12.

[7] Rogalski L, Smoczyński L, Krzebietke S, Lenart L and Mackiewicz-Walec E. (2014). Changes in sulphur dioxide concentrations in the atmospheric air assessed during short-term measurements in the vicinity of Olsztyn, Poland. Journal Elem. System, 735-748.

[8] Baciak M, Kazimierz W and Agnieszka B. (2015). The effect of selected gaseous air pollutants on woody plant. Forest Research, 76(4), 401-409.

[9] Tuygun GT, Altuğ H, Elbir T, Elbir T and Gaga EE. (2017). Modeling of air pollutant concentrations in an industrial region of Turkey. Environmental Science and Pollution Research, 24(9), 8230-8241.

[10] Hindawi IJ. (1968). Injury by Sulfur Dioxide, Hydrogen Fluoride, and Chlorine As Observed and Reflected On Vegetation in the Field. Journal of the Air Pollution Control Association, 18(5), 307-312.

[11] Hoesly RM, Smith SJ, Feng L, Klimont Z, Janssens-Maenhout G, Pitkanen T, Seibert JJ, Vu L, Andres RJ, Bolt RM, Bond TC, Dawidowski L, Kholod N, Kurokawa JI, Li M, Liu L, Lu Z, Moura MCP, O'Rourke PR and Zhang Q. (2018). Historical (1750-2014) anthropogenic emissions of reactive gases and aerosols from the Community Emissions Data System (CEDS). Geoscientific Model Development, 11, 369-408.

[12] Endress AG, Swiecki TJ and Taylor OC. (1978). Foliar and microscopic observations of bean leaves exposed to hydrogen chloride gas. Environmental and Experimental Botany, 18(2), 139-149.

[13] Vike E and Håbjørg A. (1995). Variation in fluoride content and leaf injury on plants associated with three aluminium smelters in Norway. Science of The Total Environment, 163 (1-3), 25-34.

[14] Rhimi N. (2016). Morpho-anatomical and physiological changes in grapevine leaves exposed to atmospheric fluoride and sulfur dioxide pollution. Applied Ecology and Environmental Research, 14(5), 77-89. 
[15] Schreuder MDJ and Brewer CA. (2001). Effects of Short-term, High Exposure to Chlorine Gas on Morphology and Physiology of Pinus ponderosa and Pseudotsuga menziesii. Annals of Botany, 88, 187-195.

[16] Endress AG, Kitasako JT and Taylor OC. (1967). Ultracytopathological characterization of leaves following shortterm exposures of hydrogen chloride gas. Atmospheric Environment, 12(6-7), 1383-1390.

[17] Vijayan R and Bedi SJ. (1989). Effect of chlorine pollution on three fruit tree species at ranoli near Baroda. India Environmental Pollution, 57(2), 97-102.

[18] Bessonova VP and Ponomaryova OA. (2017). Morphometric characteristics and the content of plastid pigments of the needles of Picea pungens depending on the distance from the highways. Biosystems Diversity, 25(2), 96101.

[19] Lukasik W. (1990). Zmiany zawartości barwników asymilacyjnych w wybranych gatunkach roślin runa boru sosnowego pod wpływem zanieczyszczeń. Acta Biologica Silesiana, 16, 191-202.

[20] Popek R, Przybysz A, Gawrońska H, Klamkowski K and Gawroński SW. (2018). Impact of particulate matter accumulation on the photosynthetic apparatus of roadside woody plants growing in the urban conditions. Ecotoxicol Environ Saf, 15(163), 56-62.

[21] Vasylieva N. (2018). Ukrainian Agricultural Contribution to the World Food Security: Economic Problems and Prospects. Montenegrin Journal of Economics, 14(4), 215-224.

[22] Bessonova VP. (1993). Efficacy of deposition of dust particles by leaves of shrubs and woody plants (in Russian). Issues of environmental protection and occupational safety in industry. Collection of scientific papers. Dnepropetrovsk State University. Dnepropetrovsk, 34-37.

[23] Mo L, Ma Z, Xu Y, Sun F, Lun X, Liu X, Chen J and Yu X. (2015). Assessing the Capacity of Plant Species to Accumulate Particulate Matter in Beijing. China PLoS One, 10(10), 1-14.

[24] Chen X, Zhou Zh, Teng M, Wang P and Zhou L. (2015). Accumulation of three different sizes of particulate matter on plant leaf surfaces: Effect on leaf traits. Arch. Biol. Sci., 67(4), 1257-1267.

[25] Chen L, Liu Ch, Zhang L, Zou R and Zhang Zh. (2017). Variation in Tree Species Ability to Capture and Retain Airborne Fine Particulate Matter (PM2.5) Scientific Reports, 7(3206), 1-11.

[26] Popek R, Łukowski A, Bates Ch and Oleksyn J. (2017). Accumulation of particulate matter, heavy metals, and polycyclic aromatic hydrocarbons on the leaves of Tilia cordata Mill. in five Polish cities with different levels of air pollution. International Journal of Phytoremediation, 19, 1134-1141.

[27] Bessonova VP and Ponomaryova OA. (2010). Comparative capacity of plant species of the Tilia L. genus growing in the area of sanitary protection zones of industrial enterprises to deposit dust particles (in Ukrainian). Collection of scientific papers of the Podil'skyi State Agrarian and Economic University. Kamianets-Podil'skyi, $137-140$

[28] Hassanen RA, Morsy AA and Saleh HA. (2016). Leaf Dust Accumulation and Air Pollution Tolerance Indices of Three Plant Species Exposed to Urban Particulate Matter Pollution from a Fertilizer Factory. Journal of Plant Research. Vegetos, 29(3), 1-8.

[29] Nowak DJ, Hirabayashi S, Bodine Al and Greenfield E. (2014). Tree and forest effects on air quality and human health in the United States. Environmental Pollution, 193, 119-129.

[30] Vike E. (2005). Uptake, Deposition and Wash Off of Fluoride and Aluminium in Plant Foliage in the Vicinity of an Aluminium Smelter in Norway. Water, Air, and Soil Pollution, 160 (1-4), 145-159.

[31] Sklyarenko AV and Bessonova VP. (2018). Accumulation of sulfur and glutathione in leaves of woody plants growing under the conditions of outdoor air pollution by sulfur dioxide. Biosystems Diversity, 26(4), 334-338.

[32] Dobrochaeva DN, Kotov MI and Prokudin YM. (1987). Species identification sheet of Ukraine's higher plants (in Russian). Naukova dumka, Kyiv.

[33] Kohno MA, Parkhomenko LI and Zarubenko AV. (2002). Tree flora of Ukraine. Wild and cultivated trees and shrubs (in Ukrainian). Angiosperms. Part I. Handbook, Phytosociocenter, Kiyv.

[34] Cherepanov SK. (1995). Vascular plants of Russia and adjacent states (the former USSR) (in Russian). St. Petersburg.

[35] Swain T and Hillis WE. (1959). The phenolic constituents of Prunus domestica. I. - The quantitative analysis of phenolic constituents. Journal of the Science of Food and Agriculture, 10(1), 63-68. 
[36] Khazemova LA, Radovskaya TL, Kruglova NV and Kachalkova TK. (1983). Determination of fluoride content in plant material (in Russian). Agrochemistry, 6, 66-72.

[37] Mochalova AD. (1975). Spectrophotometric method for the determination of sulfur content in plants (in Russian). Agriculture Abroad, 4, 17-27.

[38] Nesterov VG and Bobilev BM. (1967). The volumetric method for determining the leaf dry weight of forest stands (in Russian). TACA reports, Agrochemistry, plant physiology, soil science, 124, 293-295.

[39] Il'kun GV. (1978). Plants and outdoor air pollutants (in Russian). Naukova dumka, Kiev.

[40] Sergejchik SA. (1997). Ecology and plants (in Russian). Uradzhaj, Minsk.

[41] Sklyarenko AV and Bessonova VP. (2017). Taxation characteristics and life conditions of woody plants growing in the area of the sanitary protection zone of the "Ukrgrafit" PrJSC (in Ukrainian). Scientific Bulletin of NLTU of Ukraine, 27(1), 83-87.

[42] Sklyarenko AV. (2018). Characteristics of the tree flora of the protective plantations of Zaporizhzhya Aluminium Plant PJSC (in Ukrainian). Issues of bioindication and ecology, 23(2), 66-80.

[43] Spryahaylo OV. (2012). Reproductive ability of cultivated species belonging to the tree flora of Middle Dnieper Ukraine (in Ukrainian). Ukrainian Journal of Ecology, 3(6), 90-95.

[44] Bessonova VP and Ponomaryova OA. (2016). Comparative assessment of the life status of introduced and native woody plants growing in the areas next to the mainline forest belts on the Dnipropetrovs'k-Donets'k route (in Ukrainian). Plant introduction, 4, 65-72.

[45] Yavorovs'kyi PP. (2014). Barrier and sanitary roles of forests and green spaces in the urban environment (in Ukrainian). Forestry, landscaping and horticulture, 4, 1-11.

[46] Tarabrin VP, Kondratjuk VN and Bashkatov VT. (1986). Phytotoxicity of organic and inorganic pollutants (in Russian). Naukova dumka, Kiev.

[47] Smit UH. (1985). Atmosphere and forest: interactions between forest ecosystems and impurities in the outdoor air (in Russian). Progres, Moscow.

[48] Chernyshenko OV. (2000). The use of data on the absorption capacity of the urban ecosystem in various applied aspects (in Russian). Bulletin of the Moscow Forest State University - Forest Herald, 6, 33-36.

\section{How to cite this article}

Sklyarenko AV. (2020). Trade-offs in the process of enrichment of tree plantations in sanitary protection zones of enterprises regarding the peculiarities of potential accumulation of toxicants in the leaves of trees. World Journal of Advanced Research and Reviews, 6(1), 89-99. 